\title{
Methyl Jasmonate Alleviates Cadmium-Induced Photosynthetic Damages through Increased S-Assimilation and Glutathione Production in Mustard
}

\section{OPEN ACCESS}

Edited by:

Vijay Pratap Singh,

Ramanuj Pratap Singhdev Post

Graduate Government College, India

Reviewed by:

Maria Concetta De Pinto,

University of Bari Aldo Moro, Italy

Tihana Teklić,

Josip Juraj Strossmayer University of Osijek, Croatia

*Correspondence:

Tasir S. Per

tasirbot@gmail.com

Nafees A. Khan

naf9@/ycos.com

Specialty section:

This article was submitted to

Plant Physiology,

a section of the journal

Frontiers in Plant Science

Received: 26 September 2016 Accepted: 06 December 2016 Published: 22 December 2016

Citation:

Per TS, Khan NA, Masood A and Fatma M (2016) Methyl Jasmonate

Alleviates Cadmium-Induced

Photosynthetic Damages through

Increased S-Assimilation

and Glutathione Production

in Mustard. Front. Plant Sci. 7:1933.

doi: 10.3389/fp/s.2016.01933

\section{Tasir S. Per*, Nafees A. Khan*, Asim Masood and Mehar Fatma \\ Plant Physiology and Biochemistry Laboratory, Department of Botany, Aligarh Muslim University, Aligarh, India}

The effect of methyl jasmonate (MeJA) in mitigation of $50 \mu \mathrm{M}$ cadmium (Cd) toxicity on structure and function of photosynthetic apparatus in presence or absence of $1.0 \mathrm{mM}$ $\mathrm{SO}_{4}^{2-}$ was investigated in mustard (Brassica juncea L. Cv. Ro Agro 4001) at 30 days after sowing. Plants exhibited increased oxidative stress, impaired photosynthetic function when grown with $\mathrm{Cd}$, but MeJA in presence of sulfur (S) more prominently ameliorated $\mathrm{Cd}$ effects through increased S-assimilation and production of reduced glutathione (GSH) and promoted photosynthetic functions. The transmission electron microscopy showed that MeJA protected chloroplast structure against Cd-toxicity. The use of GSH biosynthetic inhibitor, buthionine sulfoximine (BSO) substantiated the findings that ameliorating effect of MeJA was through GSH production. MeJA could not alleviate Cd effects when BSO was used due to unavailability of GSH even with the input of S. The study shows that MeJA regulates S-assimilation and GSH production for protection of structure and function of photosynthetic apparatus in mustard plants under Cd stress.

Keywords: cadmium toxicity, glutathione, methyl jasmonate, oxidative stress, photosynthesis

\section{INTRODUCTION}

Cadmium $(\mathrm{Cd})$ is a non-essential toxic heavy metal and an important agricultural pollutant due to its adverse effects on metabolic processes, such as membrane damage, alteration in electron transport, activation or inhibition of enzymes activity, and DNA damage (Gallego et al., 2012; Asgher et al., 2015). Cd even at low concentration directly or indirectly targets photosynthesis and strongly inhibits growth and development (Andresen and Küpper, 2013). The indirect consequence of Cd toxicity is overproduction of reactive oxygen species (ROS); super oxide radical $\left(\mathrm{O}_{2}^{--}\right)$, hydroxyl radical $\left(\bullet^{\bullet} \mathrm{OH}\right)$, and hydrogen peroxide $\left(\mathrm{H}_{2} \mathrm{O}_{2}\right)$ (Andresen and Küpper, 2013). The higher generation of ROS accelerates lipid peroxidation by altering the composition of membrane lipids due to the formation of malondialdehyde (MDA) (Gill and Tuteja, 2010; Tian et al., 2012). Exposure of plants to $\mathrm{Cd}$ is at high risk due to the increasing industrial emissions, application of phosphatic fertilizers and sewage sludge to farm land. Thus, minimizing $\mathrm{Cd}$ concentration in crop harvests is crucial in order to curtail the hazardous effects of $\mathrm{Cd}$ on crop productivity and human health. Plants exploit several strategies to rescue from the oxidative stress caused by ROS. For this purpose, several efficient ROS-scavenging enzymes, superoxide dismutase (SOD, EC; 
1.15.1.1), ascorbate peroxidase (APX, EC; 1.11.1.11) and glutathione reductase (GR, EC; 1.6.4.2), and non-enzymatic components, ascorbic acid (AsA) and reduced glutathione (GSH) are triggered to avoid the adverse effects of ROS (Gratão et al., 2008; Foyer and Noctor, 2012; Masood et al., 2012; Roychoudhury et al., 2012; Asgher et al., 2014; Singh and Shah, 2014).

Sulfur (S) is an important nutrient element and constituent of S-containing amino acids, cysteine (Cys), and methionine (Met) which take part in the synthesis of GSH in S-assimilation pathway. GSH is the major antioxidant in plant stress defense and play an important role in trace element homeostasis ( $\mathrm{Na}$ and Salt, 2011; Capaldi et al., 2015). Uptake and assimilation of S is critical for determining crop yield and resistance to Cd stress (Gallego et al., 2012; Koprivova and Kopriva, 2014). Most agricultural soils are naturally low in fertility and can be improved by supplementation of essential mineral nutrients such as nitrogen $(\mathrm{N})$, phosphorus $(\mathrm{P})$, potassium $(\mathrm{K})$, and $\mathrm{S}$. The inadequacy of soil $\mathrm{S}$ can also cause the inefficient use of other nutrients, such as carbon and $\mathrm{N}$ leading to deficiency and decrease in protein biosynthesis, chlorophyll content and crop yield (Capaldi et al., 2015).

Plant growth hormones, auxin, gibberellins, cytokinin, abscisic acid, brassinosteroid, and jasmonic acid (JA) act as components of abiotic-stress signaling (Wani et al., 2016). JA and its methyl ester, methyl jasmonate (MeJA) are naturally occurring plant growth regulators that affect various physiological and biochemical processes in plants (Wang, 1999; Ueda and Saniewski, 2006; Norastehnia et al., 2007). Contradictory reports are available regarding the role of MeJA in protection of plants from various abiotic stresses. MeJA is generally considered to inhibit stomatal opening, photosynthetic activity and plant growth (Anjum et al., 2011; Yan et al., 2015). On the other hand, reports show that MeJA at low concentrations improves physiological responses against abiotic stress factors (Walia et al., 2007; Keramat et al., 2009). It has been found that jasmonates and MeJA counteract the toxic effects of $\mathrm{Cd}$ and lead $(\mathrm{Pb})$ in plants (Keramat et al., 2009; Moussa and El-Gamal, 2010; Singh and Shah, 2014). Some studies have indicated that MeJA applied at $10^{-7}$ to $10^{-5} \mathrm{M}$ exerts a stimulatory effect on photosynthetic pigments, photosystem II (PSII) activity that were impaired due to toxic metals (Maksymiec and Krupa, 2002; Kováčik et al., 2011). These relieving effects by JA or MeJA were associated with the enhancement of antioxidant capacity and the reduced content of thiobarbituric acid reactive substances (TBARS) and $\mathrm{H}_{2} \mathrm{O}_{2}$ (Keramat et al., 2009; Kováčik et al., 2011; Noriega et al., 2012; Singh and Shah, 2014). JA has been found to activate genes involved in the signal transduction pathway for copper $(\mathrm{Cu})$ and $\mathrm{Cd}$, up-regulated GSH-metabolic genes and potentially enhanced synthesis of GSH. Xiang and Oliver (1998) have reported that JA-induced tolerance was largely controlled at the transcriptional level by increasing mRNA level in Arabidopsis thaliana. Jasmonates also enhanced the content of GSH in Glycine max and Oryza sativa under Cd stress (Noriega et al., 2012; Singh and Shah, 2014).

Mustard (Brassica juncea L.), an important oilseed crop which exhibits higher tolerance toward most of the toxic metals/metalloids and majority of Brassica species are now known as good accumulators of toxic metals including Cd (Nouairi et al., 2006). Plants (including B. juncea) have different enzymatic mechanisms that jointly with other defense compounds play a crucial role in mitigating the toxic effects of heavy metals. In the present study, an effort was made to elucidate the effect of MeJA in S-mediated influence on photosynthetic responses and antioxidant system in mustard in presence or absence of Cd stress. First of all, the effects of MeJA on oxidative stress and photosynthesis were investigated in presence or absence of $\mathrm{Cd}$, followed by studying the effects of MeJA with or without $\mathrm{S}$ in the alleviation of $\mathrm{Cd}$ toxicity. The involvement of GSH in MeJA-mediated Cd stress tolerance using GSH biosynthetic inhibitor, buthionine sulfoximine (BSO), was also studied. Our results show that MeJA enhances tolerance to oxidative stress by increasing $\mathrm{S}$-assimilation and GSH production, and improves photosynthetic performance in mustard.

\section{MATERIALS AND METHODS}

\section{Plant Material and Growth Conditions}

Seeds of mustard (B. juncea L. cv. Ro Agro 4001) were surface sterilized with $0.01 \% \mathrm{HgCl}_{2}$ solution, rinsed with double distilled water and germinated in 23-cm diameter earthen pots filled with acid-washed sand purified according to Hewitt (1966). The plants were raised in full strength modified Hoagland nutrient solution containing $3 \mathrm{mM} \mathrm{KNO}_{3}, 2 \mathrm{mM} \mathrm{Ca}\left(\mathrm{NO}_{3}\right)_{2}, 1 \mathrm{mM} \mathrm{NH}_{4} \mathrm{H}_{3} \mathrm{PO}_{4}$, $50 \mu \mathrm{M} \mathrm{KCl}, 25 \mu \mathrm{M} \mathrm{H}_{3} \mathrm{BO}_{4}, 2 \mu \mathrm{M} \mathrm{MnCl}_{2}, 20 \mu \mathrm{M} \mathrm{ZnSO}_{4}, 0.5 \mu \mathrm{M}$ $\mathrm{CuSO}_{4}, 0.5 \mu \mathrm{M}\left(\mathrm{NH}_{4}\right)_{6} \mathrm{Mo}_{7} \mathrm{O}_{24}$, and $20 \mu \mathrm{M} \mathrm{Na} \mathrm{Na}_{2} \mathrm{Fe}$-EDTA, supplied on alternate days. After germination, three healthy plants of nearly equal size in each pot were maintained. The pots were kept in the naturally illuminated green house of the Botany Department, Aligarh Muslim University, Aligarh (India) [average day/night temperatures, $20 \pm 3$ and $12 \pm 2{ }^{\circ} \mathrm{C}$, respectively; relative humidity, $60 \pm 5 \%$; photosynthetically active radiation (PAR), $750 \pm 25 \mu \mathrm{mol} \mathrm{m}{ }^{-2} \mathrm{~s}^{-1}$; critical photoperiod, 10-12 h]. Experiments were conducted independently to evaluate the effect of $0,5,10$, and $20 \mu \mathrm{M}$ MeJA sprayed on plants at 15 days after sowing (DAS) in presence or absence of $50 \mu \mathrm{M} \mathrm{Cd}$ on content of $\mathrm{H}_{2} \mathrm{O}_{2}$ and $\mathrm{GSH}$, photosynthesis, and plant dry mass. Based on the results of this experiment, $10 \mu \mathrm{M}$ MeJA was selected for spraying on plants grown with or without $1.0 \mathrm{mM} \mathrm{SO}_{4}^{2-}$ and $50 \mu \mathrm{M} \mathrm{Cd}$ to determine the effectiveness of $\mathrm{MeJA}$ on $\mathrm{S}$-assimilation and GSH production, and alleviation of $\mathrm{Cd}$ stress. The concentration $1.0 \mathrm{mM} \mathrm{SO}_{4}^{2-}$ was used to initiate $\mathrm{S}$-assimilation and is considered as optimal concentration for mustard (Asgher et al., 2014). Cd concentration used was based on the findings of our previous results (Asgher et al., 2014; Per et al., 2016). To substantiate the role of MeJAmediated GSH production through S-assimilation in Cd stress alleviation, a GSH biosynthesis inhibitor, BSO $(0.5 \mathrm{mM})$ was added to $\mathrm{Cd}, \mathrm{MeJA}+\mathrm{Cd}$ and MeJA $+\mathrm{Cd}+\mathrm{S}$ treatments. The effects of the three treatments were compared with the effect of $\mathrm{Cd}$ treated plants alone. In experiments, $50 \mu \mathrm{M} \mathrm{Cd}$ or $1.0 \mathrm{mM} \mathrm{SO}_{4}^{2-}$ treatment was given along with nutrient 
solution at 10 DAS and observations were recorded at 30 DAS. The source of $\mathrm{Cd}$ was $\mathrm{CdCl}_{2} \cdot \mathrm{MgSO}_{4}$ was used for obtaining $1.0 \mathrm{mM} \mathrm{SO}_{4}^{2-}$ and $\mathrm{Mg}^{2+}$ was maintained in all treatments including control by the addition of appropriate $\mathrm{MgCl}_{2}$ as described earlier (Nazar et al., 2014). Each pot was supplied with $250 \mathrm{~mL}$ nutrient solution. The experiment followed a randomized complete block design and was conducted in four replications.

\section{Determination of Leaf Cd Concentration}

Leaf samples were dried for $48 \mathrm{~h}$ at $80^{\circ} \mathrm{C}$ in an oven and the dried tissue was weighed, ground to fine powder and digested with concentrated $\mathrm{HNO}_{3} / \mathrm{HClO}_{4}(3: 1, \mathrm{v} / \mathrm{v})$. The content of $\mathrm{Cd}$ was determined by atomic absorption spectrophotometer (GBC, 932 plus; GBC Scientific Instruments, Braeside, Australia).

\section{Determination of $\mathrm{H}_{2} \mathrm{O}_{2}$ Content and Lipid Peroxidation}

The content of $\mathrm{H}_{2} \mathrm{O}_{2}$ was determined by adopting the method of Okuda et al. (1991) in leaf tissues (0.5 g) grounded in icecold $200 \mathrm{mM} \mathrm{HClO}_{4}$. The sample was centrifuged at $1200 \times g$ for $10 \mathrm{~min}$ followed by neutralization of $\mathrm{HClO}_{4}$ of the supernatant with $4 \mathrm{M} \mathrm{KOH}$. The insoluble $\mathrm{KClO}_{4}$ was eliminated by further centrifugation at $500 \times g$ for $3 \mathrm{~min}$. In a final volume of $1.5 \mathrm{~mL}$, the reaction mixture contained $1 \mathrm{~mL}$ of the eluate, $400 \mu \mathrm{L}$ of $12.5 \mathrm{mM} 3$-(dimethylamino) benzoic acid in $0.375 \mathrm{M}$ phosphate buffer ( $\mathrm{pH}$ 6.5), $80 \mu \mathrm{L}$ of 3-methyl-2-benzothiazoline hydrazone, and $20 \mu \mathrm{L}$ of peroxidase ( 0.25 unit). The reaction was started by the addition of peroxidase at $25^{\circ} \mathrm{C}$ and the increase in absorbance was recorded at $590 \mathrm{~nm}$.

Lipid peroxidation in leaves was determined in terms of the content of TBARS as described by Dhindsa et al. (1981). Fresh leaf tissues $(0.5 \mathrm{~g})$ were ground in $0.25 \%$ 2-thiobarbituric acid (TBA) in 10\% trichloroacetic acid (TCA) using mortar and pestle. After heating at $95^{\circ} \mathrm{C}$ for $30 \mathrm{~min}$, the mixture was rapidly cooled on ice bath and centrifuged at $10,000 \times g$ for $10 \mathrm{~min}$. To $1 \mathrm{~mL}$ of the supernatant, $4 \mathrm{~mL} \mathrm{20 \%} \mathrm{TCA} \mathrm{containing}$ $0.5 \%$ TBA was added. The absorbance of the supernatant was read at $532 \mathrm{~nm}$ and corrected for non-specific turbidity by subtracting the absorbance of the same at $600 \mathrm{~nm}$. The content of TBARS was calculated using the extinction coefficient $\left(155 \mathrm{mM}^{-1} \mathrm{~cm}^{-1}\right)$.

\section{Determination of S-Assimilation (ATP-S Activity, S Content) and GSH Production}

The method of Lappartient and Touraine (1996) was adopted for the measurement of ATP-sulfurylase (ATP-S) activity. The activity of ATP-S was assayed in vitro in leaves by measuring molybdate-dependent formation of pyrophosphate. Fresh leaf tissues $(1.0 \mathrm{~g})$ were ground at $4^{\circ} \mathrm{C}$ in buffer consisting of $10 \mathrm{mM}$ $\mathrm{Na}_{2}$ EDTA, $20 \mathrm{mM}$ Tris- $\mathrm{HCl}$ ( $\mathrm{pH}$ 8.0), $2 \mathrm{mM}$ dithiothreitol (DTT), and $0.01 \mathrm{~g} \mathrm{~mL}^{-1}$ polyvinylpyrrolidone (PVP), using1:4 $(\mathrm{w} / \mathrm{v})$ tissue to buffer ratio. The homogenate was centrifuged at $20,000 \times g$ for $10 \mathrm{~min}$ at $4^{\circ} \mathrm{C}$. The supernatant was used for in vitro ATP-S assay. The reaction was initiated by adding $0.1 \mathrm{~mL}$ of the extract to $0.5 \mathrm{~mL}$ of the reaction mixture, which contained $7 \mathrm{mM} \mathrm{MgCl}$, $5 \mathrm{mM} \mathrm{Na}_{2} \mathrm{MoO}_{4}, 2 \mathrm{mM} \mathrm{Na} 2$ ATP, and 0.032 units $\mathrm{mL}^{-1}$ of sulfate-free inorganic pyrophosphate in $80 \mathrm{mM}$ Tris- $\mathrm{HCl}$ buffer ( $\mathrm{pH} 8.0$ ). Another aliquot from the same extract was added to the reaction mixture but without $\mathrm{Na}_{2} \mathrm{MoO}_{4}$. Incubations were carried out at $37^{\circ} \mathrm{C}$ for $15 \mathrm{~min}$, after which phosphate was determined using UV-VIS spectrophotometer (LT-2700, UV/VIS Analytical Technologies Limited, Labtronics, India).

For the determination of S content, dried leaf material ( $0.1 \mathrm{~g})$ was digested in a mixture of concentrated $\mathrm{HNO}_{3}$ and $60 \%$ strength $\mathrm{HClO}_{4}(85: 15, \mathrm{v} / \mathrm{v})$ and total $\mathrm{S}$ in plant samples was determined using turbidimetric method (Chesnin and Yien, 1950). Turbidity in $5 \mathrm{~mL}$ aliquot was developed by adding $2.5 \mathrm{~mL}$ gum acacia (0.25\%) solution, $1.0 \mathrm{~g} \mathrm{BaCl}_{2}$ sieved through $40-60 \mathrm{~mm}$ mesh and the volume was made to $25 \mathrm{~mL}$ with deionized water. The contents of $25 \mathrm{~mL}$ volumetric flask were thoroughly shaken till $\mathrm{BaCl}_{2}$ completely dissolved. The values were recorded at $415 \mathrm{~nm}$ within 10 min after the turbidity development. A blank was run simultaneously after each set of determination.

Glutathione content was determined following the method of Anderson (1985). Fresh leaves (0.5 g) were homogenized in $2.0 \mathrm{~mL}$ of $5 \%$ sulphosalicylic acid under cold conditions. The homogenate was centrifuged at $10,000 \times g$ for $10 \mathrm{~min}$. To $0.5 \mathrm{~mL}$ of supernatant, $0.6 \mathrm{~mL}$ of phosphate buffer $(100 \mathrm{mM}, \mathrm{pH} 7.0)$ and $40 \mu \mathrm{L}$ of $5^{\prime} 5^{\prime}$-dithiobis-2-nitrobenzoic acid (DTNB) were added. After $2 \mathrm{~min}$ the absorbance was read at $412 \mathrm{~nm}$. The details of the procedure are given in our earlier work (Fatma et al., 2014).

\section{Assay of Antioxidant Enzymes}

The activity of SOD was determined using the method of Giannopolitis and Ries (1977) and Beyer and Fridovich (1987), while activity of APX and GR was assayed by the Foyer and Halliwell (1976) and Nakano and Asada (1981), respectively, with slight modifications. Fresh leaf tissues $(0.2 \mathrm{~g})$ were homogenized in chilled mortar and pestle with an extraction buffer containing $0.05 \%(\mathrm{v} / \mathrm{v})$ Triton X-100 and 1\% (w/v) polyvinylpyrrolidone in $100 \mathrm{mM}$ potassium-phosphate buffer ( $\mathrm{pH} \mathrm{7.0)}$. At $4^{\circ} \mathrm{C}$, the homogenate was centrifuged at $15,000 \times g$ for $20 \mathrm{~min}$. The supernatant obtained after centrifugation was used for the assay of SOD and GR. For the assay of APX extraction buffer was supplemented with $2 \mathrm{mM}$ AsA. The details of procedure have been described earlier in Fatma et al. (2014).

\section{Measurement of Photosynthetic and Growth Parameters}

Gas exchange parameters (net photosynthesis, stomatal conductance, and intercellular $\mathrm{CO}_{2}$ concentration) were measured in fully expanded uppermost leaves of plants using infrared gas analyzer (CID-340, Photosynthesis System, BioScience, USA). The measurements were done on a sunny day at light saturating intensity; PAR; $780 \mu \mathrm{mol} \mathrm{m} \mathrm{m}^{-2} \mathrm{~s}^{-1}$ and atmospheric $\mathrm{CO}_{2}$ concentrations; $370 \pm 5 \mu \mathrm{mol} \mathrm{mol}^{-1}$.

The activity of ribulose 1,5-bisphosphate carboxylase/oxygenase (Rubisco; EC 4.1.1.39) was determined adopting the method of Usuda (1985) by monitoring NADH 
oxidation at $30^{\circ} \mathrm{C}$ at $340 \mathrm{~nm}$. For enzyme extraction, leaf tissue $(1.0 \mathrm{~g})$ was homogenized using chilled mortar and pestle with ice-cold extraction buffer containing $0.25 \mathrm{M}$ Tris- $\mathrm{HCl}(\mathrm{pH}$ 7.8), $0.05 \mathrm{M} \mathrm{MgCl}_{2}, 0.0025 \mathrm{M}$ EDTA and $37.5 \mathrm{mg}$ DTT. This homogenate was centrifuged at $4^{\circ} \mathrm{C}$ at $10,000 \times g$ for $10 \mathrm{~min}$. The resulting supernatant was used to assay the enzyme. The reaction mixture $(3 \mathrm{~mL})$ contained $100 \mathrm{mM}$ Tris- $\mathrm{HCl}(\mathrm{pH} 8.0), 40 \mathrm{mM}$ $\mathrm{NaHCO}_{3}, 10 \mathrm{mM} \mathrm{MgCl}$, $0.2 \mathrm{mM} \mathrm{NADH}, 4 \mathrm{mM}$ ATP, $5 \mathrm{mM}$ DTT, $1 \mathrm{U}$ of glyceraldehyde 3-phosphodehydrogenase, $1 \mathrm{U}$ of 3phosphoglycerate kinase, and $0.2 \mathrm{mM}$ ribulose 1,5-bisphosphate (RuBP).

Chlorophyll content was measured in the intact leaves with the help of SPAD chlorophyll meter (502 DL PLUS, Spectrum Technologies, USA). Chlorophyll $a$ fluorescence was measured using Junior-PAM chlorophyll fluorometer (Heinz Walz, Germany). Prior to the measurements of fluorescence intensity, leaf sections were dark-adapted for at least $30 \mathrm{~min}$ in order to relax the reaction center. Minimal fluorescence $\left(F_{\mathrm{o}}\right)$ and maximum fluorescence $\left(F_{\mathrm{m}}\right)$ were measured in darkadapted leaves with a low measuring beam at a light intensity of $125 \mu \mathrm{mol} \mathrm{m} \mathrm{m}^{-2} \mathrm{~s}^{-1}$, whereas under light-adapted condition, minimal fluorescence $\left(F_{\mathrm{o}^{\prime}}\right)$ and maximum fluorescence $\left(F_{\mathrm{m}^{\prime}}\right)$ were measured in the same leaves with a saturating light intensity (780 $\left.\mu \mathrm{mol} \mathrm{m}{ }^{-2} \mathrm{~s}^{-1}\right)$ together with steady-state fluorescence $\left(F_{s}\right)$. The variable fluorescence $\left(F_{\mathrm{V}}\right.$ and $\left.F_{\mathrm{V}^{\prime}}\right)$ was calculated using the values of $F_{\mathrm{m}}-F_{\mathrm{o}}$ and $F_{\mathrm{m}^{\prime}}-F_{\mathrm{o}^{\prime}}$, and actual PSII efficiency (ФPSII) was determined as $F_{\mathrm{m}^{\prime}}-F_{\mathrm{s}} / F_{\mathrm{m}^{\prime}}$, maximal efficiency of PSII by using $F_{\mathrm{v}} / F_{\mathrm{m}}$ and intrinsic efficiency of PSII by using $F_{\mathrm{v}^{\prime}} / F_{\mathrm{m}^{\prime}}$. Using fluorescence parameters determined in both the light- and dark-adapted states, the photochemical quenching $(\mathrm{qP})$ and nonphotochemical quenching (NPQ) parameters were calculated. qP was calculated as $\left(F_{\mathrm{m}^{\prime}}-F_{s}\right) / F_{\mathrm{v}^{\prime}}$ and NPQ as $\left(F_{\mathrm{m}}-F_{\mathrm{m}^{\prime}}\right) / F_{\mathrm{m}^{\prime}}$ (Maxwell and Johnson, 2000). Electron transport rate (ETR) was calculated by the following formula: $\Phi$ PSII $\times$ photosynthetic photon flux density $\times 0.5 \times 0.84$ as suggested by Krall and Edwards (1992).

Leaf tissues for chloroplast ultrastructure were prepared for transmission electron microscopy (TEM) by adopting the method of Sandalio et al. (2001) with slight modifications. Leaf samples were cut with razor blade into $1 \mathrm{~mm}^{2}$ segments and fixed in $2.5 \%$ glutaraldehyde solution in $50 \mathrm{mM}$ phosphate buffer ( $\mathrm{pH}$ 6.8) for $2.5 \mathrm{~h}$ at room temperature. Leaf tissue was then post-fixed for $30 \mathrm{~min}$ in $1 \%$ osmium tetroxide in $50 \mathrm{mM}$ sodium cacodylate buffer $(\mathrm{pH}$ 7.2) and dehydrated in ethanol graded series $(30-100 \%, v / v)$. After dehydration in a graded series of ethanol, replaced to propylene oxide, and then the tissue was embedded in Spurr resin. Ultrathin sections were taken by using Leica EM UC6 ultramicrotome. Sections were stained with uranyl acetate and lead citrate and examined using a transmission electron microscope (JEOL 2100F, JAPAN) accelerating voltage at $120 \mathrm{kV}$ and magnification at $6000 \times$ and $1200 \times$. The chloroplast ultrastructure (thylakoid membranes) was observed from TEM images.

For measuring growth characteristics, plants were uprooted, washed and dried on blotting paper, and were kept in an oven at $80^{\circ} \mathrm{C}$ till constant weight. The samples were weighed after drying to obtain dry mass. Leaf area was measured using a leaf area meter (LA211, Systronics, New Delhi, India).

\section{Statistical Analysis}

Data were analyzed statistically using analysis of variance (ANOVA) by SPSS 17.0 for Windows, and presented as treatment mean $\pm \mathrm{SE}(n=4)$. Least significant difference (LSD) was calculated for the significant data at $P<0.05$ and $P<0.01$. Bars showing the same letter are not significantly different by LSD test at $P<0.05$ or $P<0.01$.

\section{RESULTS}

\section{MeJA Protects Plants from Cd-Induced Damages}

In the absence of $\mathrm{Cd}, 5$ and $10 \mu \mathrm{M}$ MeJA did not influence content of $\mathrm{H}_{2} \mathrm{O}_{2}$, net photosynthesis and plant dry mass, but $20 \mu \mathrm{M}$ MeJA significantly increased $\mathrm{H}_{2} \mathrm{O}_{2}$ content and decreased net photosynthesis and plant dry mass as compared to the control. The GSH content remained unchanged with MeJA concentrations as compared to the control (Table 1). In the presence of $\mathrm{Cd}$, spraying of $10 \mu \mathrm{M}$ MeJA was more effective than $5 \mu \mathrm{M}$ MeJA in reducing $\mathrm{H}_{2} \mathrm{O}_{2}$ content $(-31.7 \%)$ and increasing GSH content $(+52.6 \%)$ as compared to the Cd treated plants (Table 1).

Net photosynthesis and plant dry mass were favorably influenced by MeJA treatment under Cd stress. Application of $10 \mu \mathrm{M}$ MeJA increased net photosynthesis and plant dry mass by about two-times as compared to the Cd treated plants (Table 1).

\section{MeJA Improves Tolerance to Oxidative Damage Caused by Cd Treatment}

To determine the role of MeJA in oxidative stress tolerance, we compared the effect of MeJA on oxidative damage induced by $\mathrm{Cd}$. Application of either MeJA or S reduced Cd content about equally by $93 \%$ as compared to the Cd treated plants. The combined treatment of MeJA plus S further reduced the Cd content by $156 \%$ in comparison with the Cd treated plants (Figure 1).

Plants treated with MeJA or $\mathrm{S}$ in the absence of $\mathrm{Cd}$ showed that $S$ only could reduce $\mathrm{H}_{2} \mathrm{O}_{2}$ and TBARS contents and the effect of MeJA did not differ with that of control plants. Plants treated with Cd showed an increase of about more than two-times in TBARS content as compared to the control plants. However, treatment with MeJA or $\mathrm{S}$ reduced the content of $\mathrm{H}_{2} \mathrm{O}_{2}$ and TBARS in $\mathrm{Cd}$ stressed plants almost equally by about $60 \%$, and the combined treatment $\mathrm{MeJA}+\mathrm{S}$ reduced oxidative stress in Cd stressed plants more prominently, by diminishing $\mathrm{H}_{2} \mathrm{O}_{2}$ and TBARS content by about $70 \%$ (Figure 1).

To assess the involvement of antioxidant enzymes in $\mathrm{Cd}$ tolerance, activity of SOD, APX, and GR was evaluated under Cd stress. Cd increased the activity of SOD, APX, and GR by $36 \%, 67 \%$, and $47 \%$, respectively as compared to the control. Application of S in absence of Cd increased activity of antioxidant enzymes, but MeJA application showed no significant changes in the activity of antioxidant enzymes as compared to the control. 

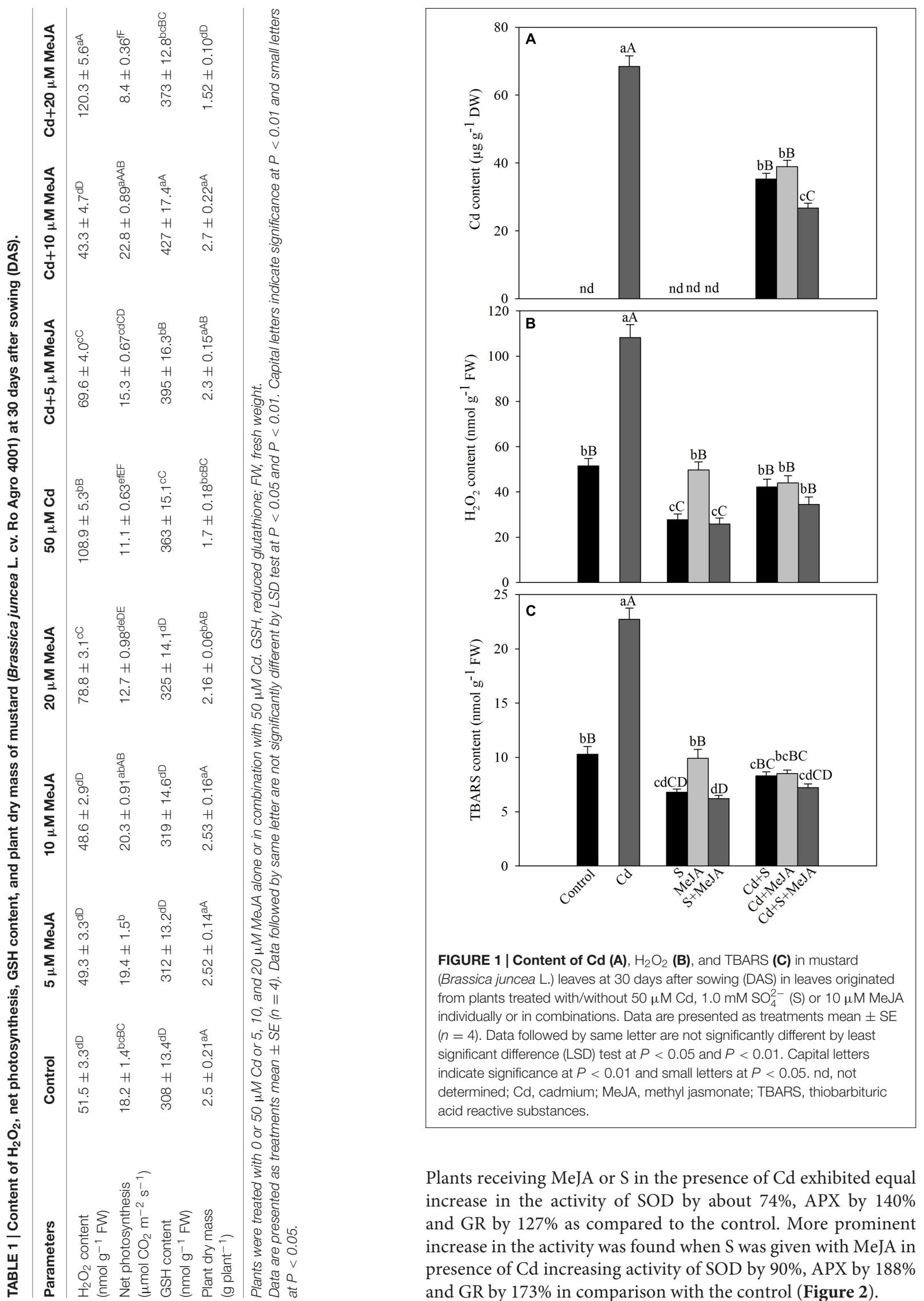

Plants receiving MeJA or $\mathrm{S}$ in the presence of Cd exhibited equal increase in the activity of SOD by about $74 \%$, APX by $140 \%$ and GR by $127 \%$ as compared to the control. More prominent increase in the activity was found when $S$ was given with MeJA in presence of Cd increasing activity of SOD by $90 \%$, APX by $188 \%$ and GR by $173 \%$ in comparison with the control (Figure 2). 


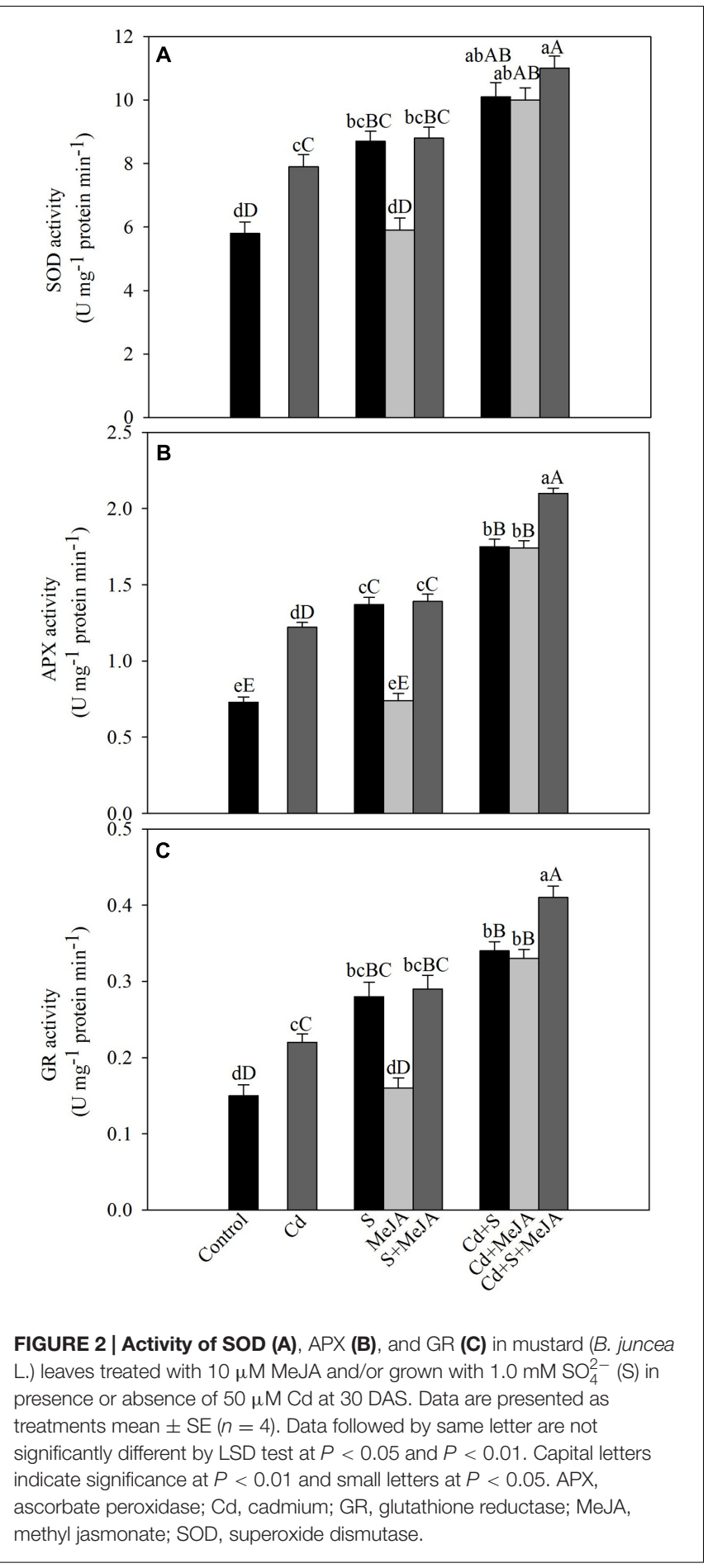

\section{MeJA Improves S-Assimilation Capacity}

Under Cd stress, activity of ATP-S increased by $31 \%$ and S content decreased by $36 \%$ in comparison with the control. Application of S or MeJA plus S increased ATP-S activity equally by about $62 \%$ and $S$ content by $26 \%$ in comparison with the control under non stress condition. MeJA alone did not produce any significant change in the activity of ATP-S and S content as compared to the control. Plants receiving S or MeJA in the presence of $\mathrm{Cd}$ showed increase in the activity of ATP-S by about $52 \%$ as compared to the $\mathrm{Cd}$ treated plants. In presence of Cd, MeJA together with S increased ATP-S activity by $67 \%$ as compared to the $\mathrm{Cd}$ treated plants (Figure 3 ).

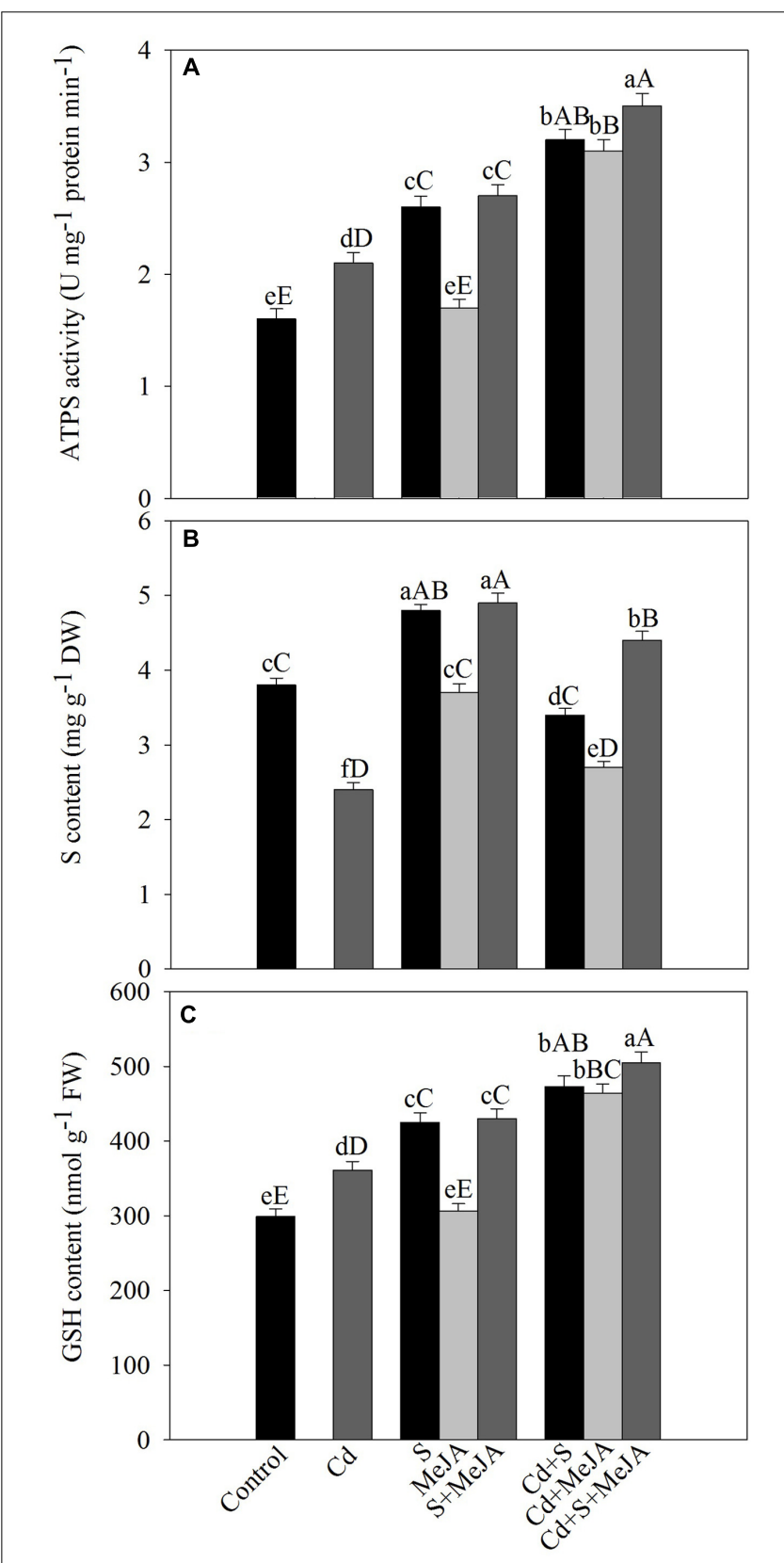

FIGURE 3 | Activity of ATP-S (A), content of S (B), and GSH (C) in mustard (B. juncea L.) leaves treated with $10 \mu \mathrm{M}$ methyl jasmonate (MeJA) and/or grown with $1.0 \mathrm{mM} \mathrm{SO}_{4}^{2-}(\mathrm{S})$ in presence or absence of $50 \mu \mathrm{M} \mathrm{Cd}$ at $30 \mathrm{DAS}$. Data are presented as treatments mean \pm SE $(n=4)$. Data followed by same letter are not significantly different by LSD test at $P<0.05$ and $P<0.01$. Capital letters indicate significance at $P<0.01$ and small letters at $P<0.05$. ATP-S, ATP-sulfurylase; Cd, cadmium; GSH, reduced glutathione; MeJA, methyl jasmonate; $\mathrm{S}$, sulfur. 
Plants grown with $\mathrm{Cd}$ showed significant increase in the content of GSH by $21 \%$ as compared to the control. Supplementation of S increased GSH by $40 \%$ in the absence of $\mathrm{Cd}$, while MeJA alone showed no significant increase in GSH content in comparison with the control. In the presence of $\mathrm{Cd}$, however, MeJA or S effectively increased GSH content equally by about $30 \%$ in comparison with the $\mathrm{Cd}$ treated plants. The combined application of MeJA and $\mathrm{S}$ in the presence of Cd more prominently increased GSH content by $40 \%$ in comparison with the Cd treated plants (Figure 3).

\section{Influence of MeJA on Photosynthetic and Growth Parameters}

Cadmium stress severely affected gas exchange parameters, chlorophyll content and Rubisco activity as compared to the control. The plants receiving S showed higher photosynthesis as compared to the control in the absence/presence of $\mathrm{Cd}$. In the presence of $\mathrm{Cd}$, plants receiving $\mathrm{S}$ or MeJA completely alleviated the Cd stress and enhanced photosynthesis as compared to the control. In the absence of $\mathrm{Cd}$, plants receiving $\mathrm{S}$ showed increase in net photosynthesis by $40 \%$, stomatal conductance by $19 \%$, intercellular $\mathrm{CO}_{2}$ concentration by $27 \%$ and chlorophyll content by $27 \%$ and Rubisco activity by $42 \%$ in comparison with the control. However, no significant increase as compared to the control was observed with MeJA application in the absence of $\mathrm{Cd}$. In Cd treated plants, application of MeJA or S was effective in enhancing net photosynthesis by 81 and 102\%, stomatal conductance by 32 and $37 \%$, intercellular $\mathrm{CO}_{2}$ concentration by 36 and $36 \%$, chlorophyll content by 74 and $83 \%$, and Rubisco activity by 84 and 100\%, respectively, as compared to the Cd treated plants. The treatment with MeJA and S together showed more pronounced increase in net photosynthesis by $117 \%$, stomatal conductance by $41 \%$, intercellular $\mathrm{CO}_{2}$ concentration by $53 \%$, chlorophyll content by $95 \%$, and Rubisco activity by $117 \%$ as compared to the Cd treated plants (Table 2).

The chlorophyll fluorescence parameters varied under different treatments. Plants grown with $\mathrm{Cd}$ exhibited reduced maximum PSII efficiency $(-13 \%)$, intrinsic PSII efficiency $(-25 \%)$, actual PSII efficiency $(-40 \%), \mathrm{qP}(-45 \%)$, and ETR
$(-40 \%)$ as compared to the control. However, NPQ increased with Cd stress by $62 \%$ as compared to the control. Application of MeJA or $\mathrm{S}$ alone improved the above characteristics equally in $\mathrm{Cd}$ treated plants in comparison with the Cd treated plants. Application of MeJA and S together more prominently reversed the effect of $\mathrm{Cd}$ on chlorophyll fluorescence parameters and resulted in increase in maximum PSII efficiency, intrinsic PSII efficiency, actual PSII efficiency, qP, and ETR by 30\%, 51\%, $96 \%, 98 \%$, and $96 \%$, respectively, and decreased NPQ by $46 \%$ in comparison with the Cd treated plants (Figure 4).

The TEM images of ultrastructure of chloroplasts from leaves samples are shown in Figure 5. Under normal conditions, chloroplasts were of regular shape with well arranged thylakoid systems. The analysis of TEM of plants grown with Cd showed disturbances in chloroplast ultrastructure. Chloroplast from Cdtreated plants showed disorganized thylakoid systems, however, plants receiving MeJA plus $\mathrm{S}$ in the presence of $\mathrm{Cd}$ greatly modified the chloroplast ultrastructure and chloroplast showed regular shape with well arranged thylakoid systems containing a markedly increased number of thylakoid stacks (Figure 5).

Cadmium stress inhibited the development of leaf area and plant dry mass. Application of S increased leaf area by $43 \%$ and plant dry mass by $17 \%$ in the absence of $\mathrm{Cd}$ in comparison with the control. MeJA alone did not prove effective in increasing leaf area and plant dry mass in the absence of $\mathrm{Cd}$. In the presence of Cd, however, MeJA or S increased leaf area equally by about $90 \%$ and plant dry mass by about $60 \%$, respectively, as compared to the Cd treated plants. More prominent increase in leaf area and plant dry mass was noted with combined treatments of MeJA and S (Figure 6).

\section{Effect of BSO on MeJA-Mediated Alleviation of Cd Stress}

Application of MeJA lowered the impact of Cd on photosynthetic parameters through increase in production of GSH via $\mathrm{S}$-assimilation. These observations were found when comparison of plants treated with $\mathrm{Cd}$ or Cd plus BSO was made with plants receiving $\mathrm{BSO}$ in presence of MeJA and $\mathrm{Cd}$ or MeJA, Cd and S. Supplementation of BSO to plants treated with MeJA in presence

TABLE 2 | Net photosynthesis, stomatal conductance, intercellular $\mathrm{CO}_{2}$ concentration, chlorophyll content and Rubisco activity of mustard (B. juncea L.

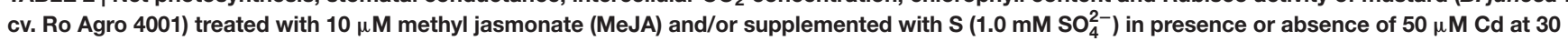
DAS.

\begin{tabular}{|c|c|c|c|c|c|}
\hline Treatments & $\begin{array}{l}\text { Net photosynthesis } \\
\left(\mu \mathrm{mol} \mathrm{CO} \mathrm{Cm}_{2}^{-2} \mathrm{~s}^{-1}\right)\end{array}$ & 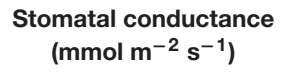 & $\begin{array}{c}\text { Intercellular } \mathrm{CO}_{2} \\
\text { concentration }\left(\mu \mathrm{mol} \mathrm{mol}^{-1}\right)\end{array}$ & $\begin{array}{l}\text { Chlorophyll content } \\
\text { (SPAD value) }\end{array}$ & $\begin{array}{c}\text { Rubisco activity } \\
\left(\mu \mathrm{mol} \mathrm{CO} \mathrm{mg}^{-1} \text { (protein) } \mathrm{s}^{-1}\right)\end{array}$ \\
\hline 0 & $17.3 \pm 0.98^{\mathrm{bb}}$ & $313 \pm 8.9^{\mathrm{bb}}$ & $215 \pm 4.8^{\mathrm{cD}}$ & $35.3 \pm 1.70^{\mathrm{cC}}$ & $44.8 \pm 1.50^{d D}$ \\
\hline S & $24.3 \pm 1.10^{\mathrm{aA}}$ & $371 \pm 7.9^{\mathrm{aA}}$ & $273 \pm 5.2^{\mathrm{aA}}$ & $44.7 \pm 1.50^{a \mathrm{~A}}$ & $63.8 \pm 1.60^{a A}$ \\
\hline MeJA & $17.6 \pm 1.22^{\mathrm{bb}}$ & $305 \pm 8.2^{\mathrm{bb}}$ & $221 \pm 5.4^{\mathrm{CCD}}$ & $36.8 \pm 1.40^{c C}$ & $45.9 \pm 1.53^{\mathrm{dD}}$ \\
\hline $\mathrm{Cd}+\mathrm{S}$ & $23.0 \pm 1.02^{\mathrm{aA}}$ & $346 \pm 10.9^{a A}$ & $242 \pm 4.6^{\mathrm{bBC}}$ & $40.5 \pm 1.25^{\mathrm{bcBC}}$ & $54.4 \pm 1.24^{\mathrm{bBC}}$ \\
\hline $\mathrm{MeJA}+\mathrm{Cd}+\mathrm{S}$ & $25.4 \pm 1.30^{a \mathrm{~A}}$ & $362 \pm 11.2^{\mathrm{aA}}$ & $262 \pm 5.0^{\mathrm{aAB}}$ & $43.2 \pm 1.20^{\mathrm{abAB}}$ & $58.7 \pm 1.47^{\mathrm{bAB}}$ \\
\hline
\end{tabular}

Data are presented as treatments mean $\pm S E(n=4)$. Data followed by same letter are not significantly different by $L S D$ test at $P<0.05$ and $P<0.01$. Capital letters indicate significance at $P<0.01$ and small letters at $P<0.05$. 

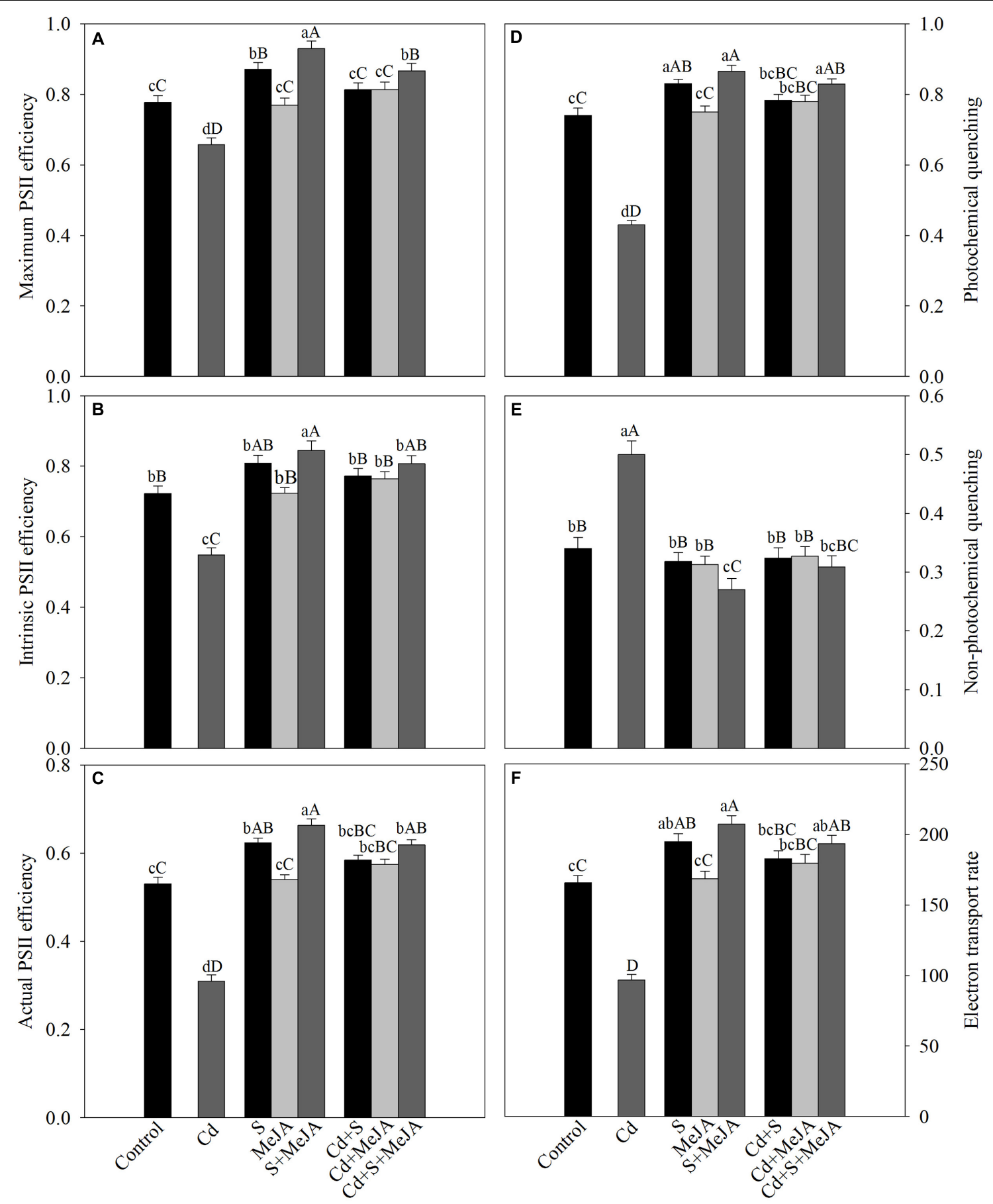

FIGURE 4 | Maximum PSII efficiency (A), intrinsic PSII efficiency (B), actual PSII efficiency (C), photochemical quenching (D), non-photochemical quenching (E), and electron transport rate $\mathbf{( F )}$ in mustard (B. juncea L.) leaves treated with $10 \mu \mathrm{M} \mathrm{MeJA}$ and/or grown with $1.0 \mathrm{mM} \mathrm{SO} \mathrm{S}_{4}^{2-}(\mathrm{S})$ in presence or absence of $50 \mu \mathrm{M} \mathrm{Cd}$ at $30 \mathrm{DAS}$. Data are presented as treatments mean $\pm \mathrm{SE}(n=4)$. Data followed by same letter are not significantly different by $\operatorname{LSD}$ test at $P<0.05$ and $P<0.01$. Capital letters indicate significance at $P<0.01$ and small letters at $P<0.05$. Cd, cadmium; MeJA, methyl jasmonate.

of Cd or MeJA in presence of $\mathrm{Cd}$ and $\mathrm{S}$ resulted in more negative effects on photosynthetic and growth parameters in comparison with the Cd treated plants. Plants raised under these treatments exhibited enhanced $\mathrm{H}_{2} \mathrm{O}_{2}$ content and lowered GSH content in comparison with the $\mathrm{Cd}$ treated plants. However, addition of $\mathrm{BSO}$ to $\mathrm{Cd}$ treated plants resulted in greatest $\mathrm{H}_{2} \mathrm{O}_{2}$ content and lowest GSH content with highest decrease in photosynthesis and growth as compared to the other treatments. The plants treated with $S$ 

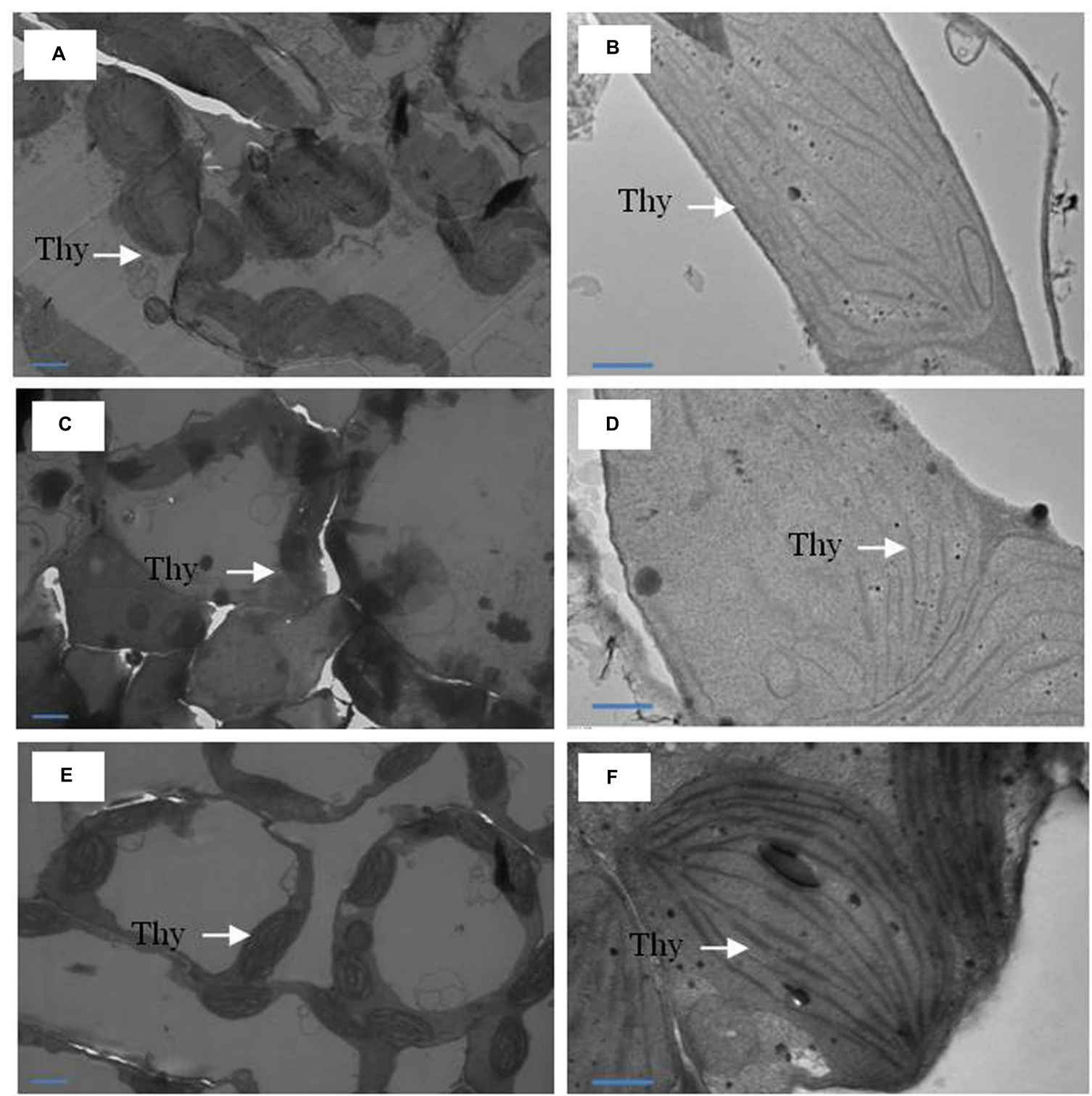

FIGURE 5 | UItrastructure of chloroplasts from leaves of mustard (B. juncea L.). Transmission electron microscopy micrographs on the representative chloroplasts from the leaves of mustard performed on the control (A,B); $50 \mu \mathrm{M} \mathrm{Cd}$ (C,D) and $1.0 \mathrm{mM} \mathrm{SO}{ }_{4}^{2-}(\mathrm{S})$ and $10 \mu \mathrm{M} \mathrm{MeJA}$ with $50 \mu \mathrm{M}$ Cd (E,F) at $30 \mathrm{DAS}$. Ultrathin sections were prepared, stained with uranyl acetate and lead citrate, and examined by transmission electron microscopy operated at voltage of $120 \mathrm{kV}$ and magnification of $6000 \times$ and $1200 \times$. Bar represents $100 \mathrm{~nm}$ in the panels (A,C,E) and $500 \mathrm{~nm}$ in the panels (B,D,F). Thy, thylakoid membranes; Cd, cadmium; MeJA, methyl jasmonate.

in presence of MeJA, Cd, and BSO showed lesser decrease in photosynthesis and growth in comparison with the plants treated with MeJA, Cd, and BSO (Table 3).

\section{DISCUSSION}

\section{Effect of MeJA on Cd Stress Tolerance}

The lipid peroxidation and $\mathrm{H}_{2} \mathrm{O}_{2}$ generation are indicators of oxidative stress and the general outcome of metal toxicity (Srivastava et al., 2014; Khan et al., 2015). Lipid peroxidation and $\mathrm{H}_{2} \mathrm{O}_{2}$ content significantly increased with the increase of $\mathrm{Cd}$ accumulation in $\mathrm{Cd}$ treated plants (Figure 1). Addition of MeJA plus S, however, maximally decreased contents of $\mathrm{H}_{2} \mathrm{O}_{2}$ and TBARS showing the ability of MeJA in alleviation of Cd-induced oxidative stress. These findings are supported by the previous results of Singh and Shah (2014), Hanaka et al. (2015) and Farooq et al. (2016). Plants under oxidative stress induce synthesis of antioxidant metabolites and activity of antioxidant enzymes for protection against oxidative stress. In this study, the application of MeJA and S in Cd-stressed plant increased the activity of antioxidant enzymes more 

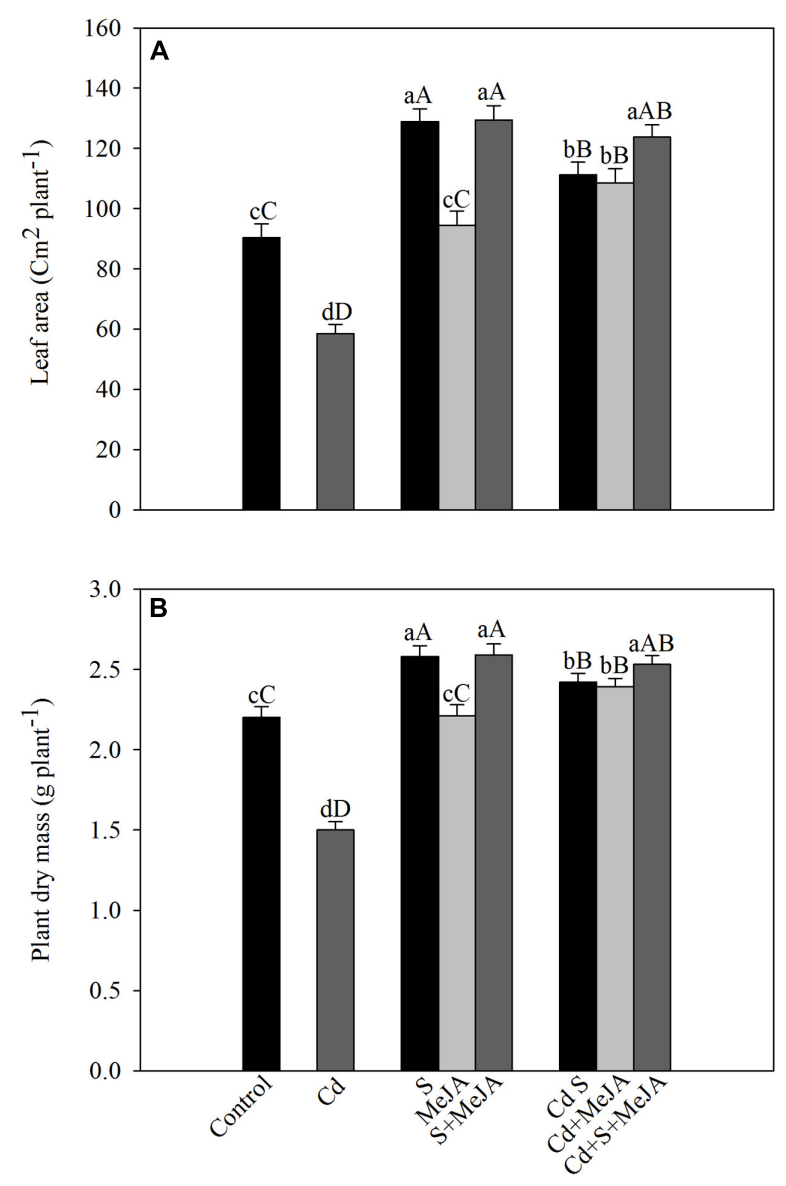

FIGURE 6 | Leaf area (A) and plant dry mass (B) of mustard (B. juncea L.) leaves treated with $10 \mu \mathrm{M}$ MeJA and/or grown with $1.0 \mathrm{mM} \mathrm{SO}_{4}^{2-}(\mathrm{S})$ in presence or absence of $50 \mu \mathrm{M}$ Cd at 30 DAS. Data are presented as treatments mean \pm SE $(n=4)$. Data followed by same letter are not significantly different by LSD test at $P<0.05$ and $P<0.01$. Capital letters indicate significance at $P<0.01$ and small letters at $P<0.05$. Cd, Cadmium; MeJA, methyl jasmonate.

than their individual application (Figure 2) and substantially decreased ROS (Figures 1B,C). Application of $5 \mu \mathrm{M}$ MeJA in O. sativa (Singh and Shah, 2014), 0.1-1.0 $\mu \mathrm{M}$ MeJA in Capsicum frutescens (Yan et al., 2013), 0.1-10 $\mu \mathrm{M}$ MeJA in Kandelia obovata (Chen et al., 2014), and $0.1 \mu \mathrm{M}$ MeJA in Solanum nigrum (Yan et al., 2015) has resulted in increased activity of antioxidant enzymes and Cd tolerance. Furthermore, application 0.1-10 $\mu \mathrm{M}$ MeJA minimized oxidative stress in As exposed B. napus plants by enhancing enzymatic activity and gene expression of antioxidant enzymes and also by regulating multiple transcriptional pathways involved in oxidative stress responses (Farooq et al., 2016).

\section{MeJA Enhances S-Assimilation and GSH Production for Cd Tolerance}

Application of MeJA or/and S increased activity of ATP-S and content of S and GSH under Cd stress (Figure 3). Studies have shown that thiol metabolism and antioxidant defense system increased in Hordeum vulgare plants subjected to metals stress (Astolfi et al., 2012). The results reported here have suggested that ATP-S plays a key role in maintaining GSH pool required for $\mathrm{Cd}$ stress tolerance. The potential of plants to survive in Cd contaminated conditions has been found to improve by upregulation of S-assimilation pathway (Wangeline et al., 2004; Bashir et al., 2013). Under normal conditions, GSH level is maintained in plant cells in a steady state via a low level of transcription, translation, and optimal enzyme activity. However, when plants are subjected to stress, the homeostasis is perturbed and GSH pool is consumed to combat stress. The increased GSH production in the presence of MeJA as observed in the present study in Cd-stressed plant is in close conformity to the results of Singh and Shah (2014) in O. sativa under Cd stress and Farooq et al. (2016) in B. napus under As stress, who found that antioxidant system was stimulated with MeJA. Plants with improved capacity for GSH synthesis have been found to display higher Cd-tolerance (Schützendübel et al., 2002; Yan et al., 2015). Xiang and Oliver (1998) have reported that JA treatment increased the transcript levels of $\gamma$-ECS (GHS1) and GSH2 as well as GR and also several GSH-Stransferase encoding genes (Schenk et al., 2000; Sasaki et al., 2001).

\section{MeJA Improves Photosynthesis and Growth under Cd Stress}

The increase in Rubisco activity with MeJA suggests restoration of photosynthetic apparatus in Cd-stressed plants. The role of MeJA in protecting plants under various abiotic stresses is controversial. However, our results have shown that individual or combined application of MeJA and S favored S-assimilation and GSH synthesis. This cumulatively protected chloroplast ultrastructure. Iqbal et al. (2012) have shown the relationship between $\mathrm{S}$ allocation in leaves and Rubisco activity. The decreased chlorophyll content in response to Cd supply was related to disorganization in chlorophyll biosynthesis (Parmar et al., 2013). $\mathrm{MeJA}$ at $100 \mu \mathrm{M}$ or higher concentration repressed germination (Kobayashi et al., 2010) and plant growth (Jubany-Marí et al., 2010), Rubisco genes, chlorophyll $a / b$-binding protein, light harvesting complex II (Jung et al., 2007). In contrast, lower MeJA concentration mostly stimulated plant growth, lateral root initiation, dry matter accumulation, photosynthetic pigment levels, and net photosynthetic rate (Tung et al., 1996; Mabood et al., 2006; Piotrowska et al., 2010; Wu et al., 2012). Our study showed that $10 \mu \mathrm{M}$ MeJA improved chlorophyll content, gas exchange parameters and Rubisco activity under Cd stress. This was associated with the activation of antioxidant enzymes and recovery of photosynthetic efficiency. Keramat et al. (2010) have also reported that $\mathrm{MeJA}$ at $0.01 \mathrm{mM}$ was more effective in reducing the damages of $\mathrm{Cd}$ stress on shoot dry weight and total chlorophyll content in G. max. Recently, it has been shown that $\mathrm{S}$ and $\mathrm{Se}$ increased photosynthesis via increase in the allocation of $\mathrm{N}$ and $\mathrm{S}$ to Rubisco in B. juncea and Triticum aestivum crops (Fatma et al., 2014; Khan et al., 2015). 
TABLE 3 | Content of $\mathrm{H}_{2} \mathrm{O}_{2}$, GSH, net photosynthesis, stomatal conductance, intercellular $\mathrm{CO}_{2}$ concentration, chlorophyll content, Rubisco activity, PSII

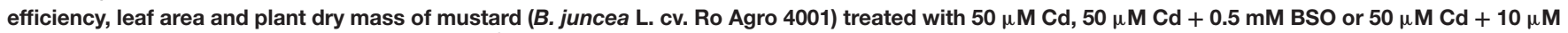
$\mathrm{MeJA}+0.5 \mathrm{mM}$ BSO or $50 \mu \mathrm{M} \mathrm{Cd}+1.0 \mathrm{mM} \mathrm{SO}_{4}^{2-}+10 \mu \mathrm{M} \mathrm{MeJA}+0.5 \mathrm{mM}$ BSO at $30 \mathrm{DAS}$.

\begin{tabular}{|c|c|c|c|c|}
\hline Parameters & Cd & Cd + BSO & MeJA + Cd + BSO & $\mathrm{MeJA}+\mathrm{Cd}+\mathrm{S}+\mathrm{BSO}$ \\
\hline $\mathrm{H}_{2} \mathrm{O}_{2}$ content (nmol g-1 FW) & $105.4 \pm 5.1^{\mathrm{dD}}$ & $216.4 \pm 3.99^{\mathrm{aA}}$ & $180.3 \pm 3.95^{\mathrm{bB}}$ & $138.2 \pm 4.03^{\mathrm{cC}}$ \\
\hline GSH content (nmol g $\left.{ }^{-1} \mathrm{FW}\right)$ & $371 \pm 10.2^{\mathrm{aA}}$ & $163 \pm 7.4^{\mathrm{dD}}$ & $194 \pm 8.2^{\mathrm{cC}}$ & $218 \pm 9.4^{\mathrm{bB}}$ \\
\hline Net photosynthesis ( $\mu \mathrm{mol} \mathrm{CO}_{2} \mathrm{~m}^{-2} \mathrm{~s}^{-1}$ ) & $15.8 \pm 0.69^{\mathrm{aA}}$ & $6.0 \pm 0.12^{\mathrm{dC}}$ & $6.6 \pm 0.26^{c C}$ & $8.1 \pm 0.26^{\mathrm{bB}}$ \\
\hline Stomatal conductance $\left(\mathrm{mmol} \mathrm{m} \mathrm{m}^{-2} \mathrm{~s}^{-1}\right)$ & $258 \pm 8.8^{\mathrm{aA}}$ & $172 \pm 5.0^{\mathrm{dC}}$ & $205 \pm 4.8^{\mathrm{cBC}}$ & $229 \pm 5.2^{\mathrm{bB}}$ \\
\hline Intercellular $\mathrm{CO}_{2}$ concentration $\left(\mu \mathrm{mol} \mathrm{mol}{ }^{-1}\right.$ ) & $181 \pm 6.6^{\mathrm{aA}}$ & $110 \pm 4.1^{d C}$ & $135 \pm 4.2^{\mathrm{cBC}}$ & $155 \pm 4.4^{\mathrm{bB}}$ \\
\hline Chlorophyll content (SPAD value) & $23.2 \pm 1.1^{\mathrm{aA}}$ & $11.1 \pm 0.73^{\mathrm{dD}}$ & $12.8 \pm 0.69^{\mathrm{cC}}$ & $16.5 \pm 0.62^{\mathrm{bB}}$ \\
\hline Rubisco activity ( $\mu \mathrm{mol} \mathrm{CO} 2 \mathrm{mg}^{-1}$ (protein) $\mathrm{s}^{-1}$ ) & $27.9 \pm 1.12^{\mathrm{aA}}$ & $16.1 \pm 0.59^{\mathrm{dD}}$ & $18.0 \pm 0.49^{\mathrm{cC}}$ & $25.2 \pm 0.51^{\mathrm{bB}}$ \\
\hline PSIl efficiency $\left(F_{\mathrm{v}} / F_{\mathrm{m}}\right)$ & $0.659 \pm 0.0126^{\mathrm{aA}}$ & $0.419 \pm 0.0104^{\mathrm{dD}}$ & $0.512 \pm 0.0122^{\mathrm{cC}}$ & $0.609 \pm 0.013^{\mathrm{bB}}$ \\
\hline Leaf area $\left(\mathrm{cm}^{2}\right.$ plant $\left.^{-1}\right)$ & $60.3 \pm 2.8^{\mathrm{aA}}$ & $23.6 \pm 2.0^{\mathrm{dD}}$ & $33.3 \pm 2.3^{\mathrm{cC}}$ & $49.4 \pm 2.3^{\mathrm{bB}}$ \\
\hline Plant dry mass (g plant ${ }^{-1}$ ) & $1.53 \pm 0.05^{\mathrm{aA}}$ & $1.08 \pm 0.04^{\mathrm{dD}}$ & $1.16 \pm 0.04^{\mathrm{cC}}$ & $1.27 \pm 0.04^{\mathrm{bB}}$ \\
\hline
\end{tabular}

BSO, buthionine sulfoximine; FW, fresh weight; GSH, reduced glutathione; MeJA, methyl jasmonate.

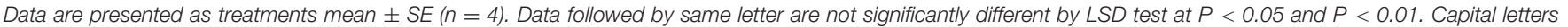
indicate significance at $P<0.01$ and small letters at $P<0.05$.

The drop in chlorophyll fluorescence under HMs stress results from destruction of antenna pigments by the partial block of electron transport from PSII to PSI (Krupa et al., 1993). The application of MeJA together with $S$ prevented the chloroplast structural damage under $\mathrm{Cd}$ stress (Figure 5). It has been suggested that the lipid-to-chlorophyll ratio is a good estimate for the protein-packing density in thylakoid, and the high lipid-to-chlorophyll ratio reflects a low protein-packing density (Kirchhoff, 2013). In the present study, plants receiving MeJA and $\mathrm{S}$ exhibited lower level of lipid peroxidation and showed higher chlorophyll content than control or Cd treated plants. A coordinated impact of MeJA and S on the ultrastructural changes of chloroplasts under $\mathrm{Cd}$ stress has not been described earlier.

The increase in growth with MeJA or/and $S$ is attributed to GSH-mediated changes in photosynthesis. The maximum alleviation of $\mathrm{Cd}$ stress on growth was observed with the combined treatment of MeJA plus S apparently because of more efficient S-assimilation and GSH production that resulted in maximum protection of cell (Figure 6). MeJA treatment has also been reported to reduce the toxic effects of $\mathrm{Cd}$ and restored plant growth (Keramat et al., 2009; Kováčik et al., 2011; Yan et al., 2015). Similarly, 0.001 and $0.01 \mathrm{mM} \mathrm{MeJA}$ alleviated $\mathrm{Cu}$ and $\mathrm{Cd}$ ions toxicity on growth in A. thaliana (Maksymiec and Krupa, 2002; Yan et al., 2013).

\section{Involvement of GSH in MeJA-Mediated Alleviation of Cd Stress and Protection of Photosynthesis}

There was involvement of MeJA in production of GSH through its effect on S-assimilation and protection of photosynthesis under Cd stress. MeJA enhanced S utilization in GSH synthesis under $\mathrm{Cd}$ stress, so that the highest GSH content was observed in $\mathrm{Cd}+\mathrm{S}+\mathrm{MeJA}$ treated plants. The same plants showed also the highest ATP-S activity (Figure 3), the lowest $\mathrm{Cd}$ content among stressed plants (Figure 1A), and the highest antioxidant response (Figure 2). Application of BSO to plants treated with $\mathrm{Cd}$ reduced production of GSH and inhibited photosynthesis, but GSH production and photosynthesis were higher in plants receiving MeJA or MeJA and S under Cd stress (Table 3). This reduction in GSH production aggravated oxidative damage significantly by increasing $\mathrm{H}_{2} \mathrm{O}_{2}$ production and consequently reduced photosynthesis and growth characteristics. In the presence $\mathrm{S}$, MeJA stimulated GSH production via increased S-assimilation under $\mathrm{Cd}$ even with the supplementation of BSO. It has been suggested that MeJA either up-regulated the expression of genes involved in biosynthesis of GSH or facilitated the synthesis of GSH (Xiang and Oliver, 1998; Farooq et al., 2016) and enhanced peroxide removal and eventually photosynthetic efficiency under Cd stress. Therefore, MeJA-mediated protection of photosynthesis under $\mathrm{Cd}$ stress was correlative with GSH production.

\section{CONCLUSION}

In conclusion, it may be said that application of MeJA and $S$ prominently mitigated the adverse effects of $\mathrm{Cd}$ stress on B. juncea through increase in S-assimilation and GSH production and promoted photosynthesis, chlorophyll fluorescence and growth. The application of MeJA induced tolerance in B. juncea plants against $\mathrm{Cd}$ stress by maintaining production of GSH which played a key role in scavenging ROS. These findings were substantiated with the use of BSO that showed that plants treated with BSO prominently reversed the effects of MeJA with or without S. Further studies are needed to elucidate how MeJA-induced GSH biosynthesis for alleviation of Cd stress.

\section{AUTHOR CONTRIBUTIONS}

TP designed and conducted the experiment, AM, MF helped in data analysis and presentation, while NK overall supervised the work and corrected the manuscript. 


\section{ACKNOWLEDGMENTS}

Financial assistance from the Department of Biotechnology (DBT), Government of India, New Delhi under the scheme of

\section{REFERENCES}

Anderson, M. E. (1985). Determination of glutathione and glutathione disulfide in biological samples. Methods Enzymol. 113, 548-555. doi: 10.1016/S00766879(85)13073-9

Andresen, E., and Küpper, H. (2013). "Cadmium toxicity in plants," in Cadmium: From Toxicity to Essentiality, eds A. Sigel, H. Sigel, and R. K. O. Sige (Dordrecht: Springer), 395-413.

Anjum, S. A., Xie, X. Y., Farooq, M., Wang, L. C., Xue, L. I., Shahbaz, M., et al. (2011). Effect of exogenous methyl jasmonate on growth, gas exchange and chlorophyll contents of soybean subjected to drought. Afr. J. Biotechnol. 24, 9647-9656.

Asgher, M., Khan, M. I., Anjum, N. A., and Khan, N. A. (2015). Minimising toxicity of cadmium in plants-role of plant growth regulators. Protoplasma 252, 399-413. doi: 10.1007/s00709-014-0710-4

Asgher, M., Khan, N. A., Khan, M. I., Fatma, M., and Masood, A. (2014). Ethylene production is associated with alleviation of cadmium-induced oxidative stress by sulfur in mustard types differing in ethylene sensitivity. Ecotoxicol. Environ. Saf. 31, 54-61. doi: 10.1016/j.ecoenv.2014.04.017

Astolfi, S., Zuchi, S., Neumann, G., Cesco, S., di Toppi, L. S., and Pinton, R. (2012). Response of barley plants to Fe deficiency and Cd contamination as affected by S starvation. J. Exp. Bot. 63, 1241-1250. doi: 10.1093/jxb/err344

Bashir, H., Ahmad, J., Bagheri, R., Nauman, M., and Qureshi, M. I. (2013). Limited sulfur resource forces Arabidopsis thaliana to shift towards non-sulfur tolerance under cadmium stress. Environ. Exp. Bot. 94, 19-32. doi: 10.1016/j.envexpbot. 2012.05.004

Beyer, W., and Fridovich, I. (1987). Assaying for superoxide dismutase activity: some large consequences of minor changes in conditions. Anal. Biochem. 161, 559-566. doi: 10.1016/0003-2697(87)90489-1

Capaldi, F. R., Gratão, P. L., Reis, A. R., Lima, L. W., and Azevedo, R. A. (2015). Sulfur metabolism and stress defense responses in plants. Trop. Plant Biol. 8, 60-73. doi: 10.1007/s12042-015-9152-1

Chen, J., Yan, Z., and Li, X. (2014). Effect of methyl jasmonate on cadmium uptake and antioxidative capacity in Kandelia obovata seedlings under cadmium stress. Ecotoxicol. Environ. Saf. 104, 349-356. doi: 10.1016/j.ecoenv.2014. 01.022

Chesnin, L., and Yien, C. H. (1950). Turbidimetric determination of available sulphates. Soil Sci. Soc. Am. Proc. 15, 149-151. doi: 10.2136/sssaj1951. 036159950015000C0032x

Dhindsa, R. H., Plumb-Dhindsa, P., and Thorpe, T. A. (1981). Leaf senescence correlated with increased level of membrane permeability, lipid peroxidation and decreased level of SOD and CAT. J. Exp. Bot. 32, 93-101. doi: 10.1093/jxb/ 32.1 .93

Farooq, M. A., Gill, R. A., Islam, F., Ali, B., Liu, H., Xu, J., et al. (2016). Methyl jasmonate regulates antioxidant defense and suppresses arsenic uptake in Brassica napus L. Front. Plant Sci. 7:468. doi: 10.3389/fpls.2016. 00468

Fatma, M., Asgher, M., Masood, A., and Khan, N. A. (2014). Excess sulfur supplementation improves photosynthesis and growth in mustard under salt stress through increased production of glutathione. Environ. Exp. Bot. 107, 55-63. doi: 10.1016/j.envexpbot.2014.05.008

Foyer, C. H., and Halliwell, B. (1976). The presence of glutathione and glutathione reductase in chloroplasts: a proposed role in ascorbic acid metabolism. Planta 133, 21-25. doi: 10.1007/BF00386001

Foyer, C. H., and Noctor, G. (2012). Managing the cellular redox hub in photosynthetic organisms. Plant Cell Environ. 35, 199-201. doi: 10.1111/j.13653040.2011.02453.x

Gallego, S. M., Pena, L. B., Barcia, R. A., Azpilicueta, C. E., Iannone, M. F., Rosales, E. P., et al. (2012). Unravelling cadmium toxicity and tolerance in plants: insight into regulatory mechanisms. Environ. Exp. Bot. 30, 33-46. doi: 10.1016/j.enve xpbot.2012.04.006
DBT-BUILDER programme (No. BT/PR4872/INF/22/150/2012) is gratefully acknowledged. The instrumentation facilities used in University Sophisticated Instrumentation Facility (USIF) at Aligarh Muslim University, Aligarh is also acknowledged.

Giannopolitis, C. N., and Ries, S. K. (1977). Superoxide dismutases II purification and quantitative relationship with water-soluble protein in seedlings. Plant Physiol. 59, 315-318. doi: 10.1104/pp.59.2.315

Gill, S. S., and Tuteja, N. (2010). Reactive oxygen species and antioxidant machinery in abiotic stress tolerance in crop plants. Plant Physiol. Biochem. 48, 909-930. doi: 10.1016/j.plaphy.2010.08.016

Gratão, P. L., Monteiro, C. C., Antunes, A. M., Peres, L. E., and Azevedo, R. A. (2008). Acquired tolerance of tomato (Lycopersicon esculentum cv. MicroTom) plants to cadmium-induced stress. Ann. Appl. Biol. 153, 321-333. doi: 10.1111/j.1744-7348.2008.00299.x

Hanaka, A., Maksymiec, W., and Bednarek, W. (2015). The effect of methyl jasmonate on selected physiological parameters of copper-treated Phaseolus coccineus plants. Plant Growth Regul. 77, 167-177. doi: 10.1007/s10725-0150048-8

Hewitt, E. J. (1966). Sand and water culture methods used in the study of plant nutrition. Tech. Commun. 22, 547.

Iqbal, N., Khan, N. A., Nazar, R., and da Silva, J. A. T. (2012). Ethylene-stimulated photosynthesis results from increased nitrogen and sulfur assimilation in mustard types that differ in photosynthetic capacity. Environ. Exp. Bot. 78, 84-90. doi: 10.1016/j.envexpbot.2011.12.025

Jubany-Marí, T., Prinsen, E., Munné-Bosch, S., and Alegre, L. (2010). The timing of methyl jasmonate, hydrogen peroxide and ascorbate accumulation during water deficit and subsequent recovery in the Mediterranean shrub Cistus albidus L. Environ. Exp. Bot. 69, 47-55. doi: 10.1016/j.envexpbot.2010.02.003

Jung, C., Yeu, S. Y., Koo, Y. J., Kim, M., Do Choi, Y., and Cheong, J. J. (2007). Transcript profile of transgenic Arabidopsis constitutively producing methyl jasmonate. J. Plant Biol. 50, 12-17. doi: 10.1007/BF03030594

Keramat, B., Kalantari, K. M., and Arvin, M. J. (2009). Effects of methyl jasmonate in regulating cadmium induced oxidative stress in soybean plant (Glycine max L.). Afr. J. Microbiol. Res. 31, 240-244.

Keramat, B., Kalantari, K. M., and Arvin, M. J. (2010). Effects of methyl jasmonate treatment on alleviation of cadmium damages in soybean. J. Plant Nutr. 33, 1016-1025. doi: 10.1080/01904161003728685

Khan, M. I. R., Nazir, F., Asgher, M., Per, T. S., and Khan, N. A. (2015). Selenium and sulfur influence ethylene formation and alleviate cadmiuminduced oxidative stress by improving proline and glutathione production in wheat. J. Plant Physiol. 173, 9-18. doi: 10.1016/j.jplph.2014.09.011

Kirchhoff, H. (2013). Architectural switches in plant thylakoid membranes. Photosyn. Res. 116, 481-487. doi: 10.1007/s11120-013-9843-0

Kobayashi, H., Yanaka, M., and Ikeda, T. M. (2010). Exogenous methyl jasmonate alters trichome density on leaf surfaces of Rhodes grass (Chloris gayana Kunth). J. Plant Growth Regul. 29, 506-511. doi: 10.1007/s00344-010-9161-0

Koprivova, A., and Kopriva, S. (2014). Molecular mechanisms of regulation of sulfate assimilation: first steps on a long road. Front. Plant Sci. 29:589. doi: 10.3389/fpls.2014.00589

Kováčik, J., Klejdus, B., Štork, F., Hedbavny, J., and Bačkor, M. (2011). Comparison of methyl jasmonate and cadmium effect on selected physiological parameters in Scenedesmus quadricauda (chlorophyta, chlorophyceae). J. Phycol. 47, 10441049. doi: 10.1111/j.1529-8817.2011.01027.x

Krall, J. P., and Edwards, G. E. (1992). Relationship between photosystem II activity and CO2 fixation in leaves. Physiol. Plant. 86, 180-187. doi: 10.1111/j.13993054.1992.tb01328.x

Krupa, Z., Öquist, G., and Huner, N. (1993). The effects of cadmium on photosynthesis of Phaseolus vulgaris-a fluorescence analysis. Physiol. Plant. 88, 626-630. doi: 10.1111/j.1399-3054.1993.tb01381.x

Lappartient, A. G., and Touraine, B. (1996). Demand-driven control of root ATPsulfurylase activity and SO42- uptake in intact canola. Plant Physiol. 111, 147-157. doi: 10.1104/pp.111.1.147

Mabood, F., Zhou, X., Lee, K. D., and Smith, D. L. (2006). Methyl jasmonate, alone or in combination with genistein, and Bradyrhizobium japonicum increases soybean (Glycine max L.) plant dry matter production and grain yield under 
short season conditions. Field Crop Res. 95, 412-419. doi: 10.1016/j.fcr.2005. 04.013

Maksymiec, W., and Krupa, Z. (2002). The in vivo and in vitro influence of methyl jasmonate on oxidative processes in Arabidopsis thaliana leaves. Acta Physiol. Plant. 24, 351-357. doi: 10.1007/s11738-002-0029-1

Masood, A., Iqbal, N., and Khan, N. A. (2012). Role of ethylene in alleviation of cadmium-induced photosynthetic capacity inhibition by sulphur in mustard. Plant Cell Environ. 35, 524-533. doi: 10.1111/j.1365-3040.2011.02432.x

Maxwell, K., and Johnson, G. N. (2000). Chlorophyll fluorescence-a practical guide. J. Exp. Bot. 51, 659-668. doi: 10.1093/jexbot/51.345.659

Moussa, H. R., and El-Gamal, S. M. (2010). Role of salicylic acid in regulation of cadmium toxicity in wheat (Triticum aestivum L.). J. Plant Nutr. 28, 1460-1471. doi: 10.1080/01904167.2010.489984

Na, G., and Salt, D. E. (2011). The role of sulfur assimilation and sulfur-containing compounds in trace element homeostasis in plants. Environ. Exp. Bot. 72, 18-25. doi: 10.1016/j.envexpbot.2010.04.004

Nakano, Y., and Asada, K. (1981). Hydrogen peroxide is scavenged by ascorbatespecific peroxidase in spinach chloroplasts. Plant Cell Physiol. 22, 867-880.

Nazar, R., Khan, M. I. R., Iqbal, N., Masood, A., and Khan, N. A. (2014). Involvement of ethylene in reversal of salt-inhibited photosynthesis by sulfur in mustard. Physiol. Plant. 152, 331-344. doi: 10.1111/ppl.12173

Norastehnia, A., Sajedi, R. H., and Nojavan-Asghari, M. (2007). Inhibitory effects of methyl jasmonate on seed germination in maize (Zea mays): effect on $\alpha$-amylase activity and ethylene production. Gen. Appl. Plant Physiol. 33, 13-23.

Noriega, G., Santa Cruz, D., Batlle, A., Tomaro, M., and Balestrasse, K. (2012). Heme oxygenase is involved in the protection exerted by jasmonic acid against cadmium stress in soybean roots. J. Plant Growth Regul. 31, 79-89. doi: 10.1007/ s00344-011-9221-0

Nouairi, I., Ammar, W. B., Youssef, N. B., Daoud, D. B., Ghorbal, M. H., and Zarrouk, M. (2006). Comparative study of cadmium effects on membrane lipid composition of Brassica juncea and Brassica napus leaves. Plant Sci. 2006, 511-519. doi: 10.1016/j.plantsci.2005.10.003

Okuda, T., Masuda, Y., Yamanka, A., and Sagisaka, S. (1991). Abrupt increase in the level of hydrogen peroxide in leaves of winter wheat is caused by cold treatment. Plant Physiol. 97, 1265-1267. doi: 10.1104/pp.97.3.1265

Parmar, P., Kumari, N., and Sharma, V. (2013). Structural and functional alterations in photosynthetic apparatus of plants under cadmium stress. Bot. Stud. 54: 45. doi: 10.1186/1999-3110-54-45

Per, T. S., Khan, S., Asgher, M., Bano, B., and Khan, N. A. (2016). Photosynthetic and growth responses of two mustard cultivars differing in phytocystatin activity under cadmium stress. Photosynthetica 54, 491-501.

Piotrowska, A., Bajguz, A., Czerpak, R., and Kot, K. (2010). Changes in the growth, chemical composition, and antioxidant activity in the aquatic plant Wolffia arrhiza (L.) Wimm. (Lemnaceae) exposed to jasmonic acid. J. Plant Growth Regul. 29, 53-62. doi: 10.1007/s00344-009-9113-8

Roychoudhury, A., Basu, S., and Sengupta, D. N. (2012). Antioxidants and stressrelated metabolites in the seedlings of two indica rice varieties exposed to cadmium chloride toxicity. Acta Physiol. Plant. 34, 835-847. doi: 10.1007/ s11738-011-0881-y

Sandalio, L. M., Dalurzo, H. C., Gomez, M., Romero-Puertas, M. C., and Del Rio, L. A. (2001). Cadmium-induced changes in the growth and oxidative metabolism of pea plants. J. Exp. Bot. 52, 2115-2126.

Sasaki, Y., Asamizu, E., Shibata, D., Nakamura, Y., Kaneko, T., Awai, K., et al. (2001). Monitoring of methyl jasmonate-responsive genes in Arabidopsis by cDNA macroarray: self-activation of jasmonic acid biosynthesis and crosstalk with other phytohormone signaling pathways. DNA Res. 8, 153-161. doi: 10 . 1093/dnares/8.4.153

Schenk, P. M., Kazan, K., Wilson, I., Anderson, J. P., Richmond, T., Somerville, S. C., et al. (2000). Coordinated plant defense responses in Arabidopsis revealed by microarray analysis. Proc. Natl. Acad. Sci. U.S.A. 97, 11655-11660. doi: 10.1073/pnas.97.21.11655

Schützendübel, A., Nikolova, P., Rudolf, C., and Polle, A. (2002). Cadmium and $\mathrm{H} 2 \mathrm{O} 2$-induced oxidative stress in Populus $\times$ canescens roots. Plant Physiol. Biochem. 40, 577-584. doi: 10.1016/S0981-9428(02)01411-0

Singh, I., and Shah, K. (2014). Exogenous application of methyl jasmonate lowers the effect of cadmium-induced oxidative injury in rice seedlings. Phytochemistry 31, 57-66. doi: 10.1016/j.phytochem.2014.09.007

Srivastava, R. K., Pandey, P., Rajpoot, R., Rani, A., and Dubey, R. S. (2014). Cadmium and lead interactive effects on oxidative stress and antioxidative responses in rice seedlings. Protoplasma 251, 1047-1065. doi: 10.1007/s00709014-0614-3

Tian, S. K., Lu, L. L., Yang, X. E., Huang, H. G., Wang, K., and Brown, P. H. (2012). Root adaptations to cadmium-induced oxidative stress contribute to Cd tolerance in the hyperaccumulator Sedum alfredii. Biol. Plant. 56, 344-350. doi: 10.1007/s10535-012-0096-0

Tung, P., Hooker, T. S., Tampe, P. A., Reid, D. M., and Thorpe, T. A. (1996). Jasmonic acid: effects on growth and development of isolated tomato roots cultured in vitro. Internatl. J. Plant Sci. 157, 713-721. doi: 10.1086/297393

Ueda, J., and Saniewski, M. (2006). Methyl jasmonate-induced stimulation of chlorophyll formation in the basal part of tulip bulbs kept under natural light conditions. J. Fruit Ornam. Plant Res. 14, 199-210.

Usuda, H. (1985). The activation state of ribulose 1, 5-bisphosphate carboxylase in maize leaves in dark and light. Plant Cell Physiol. 26, 1455-1463.

Walia, H., Wilson, C., Condamine, P., Liu, X., Ismail, A. M., and Close, T. J. (2007). Large-scale expression profiling and physiological characterization of jasmonic acid-mediated adaptation of barley to salinity stress. Plant Cell Environ. 30, 410-421. doi: 10.1111/j.1365-3040.2006.01628.x

Wang, S. Y. (1999). Methyl jasmonate reduces water stress in strawberry. J. Plant Growth Regul. 18, 127-134. doi: 10.1007/PL00007060

Wangeline, A. L., Burkhead, J. L., Hale, K. L., Lindblom, S. D., Terry, N., Pilon, M., et al. (2004). Overexpression of ATP sulfurylase in indian mustard. J. Environ. Q. 33, 54-60. doi: 10.2134/jeq2004.5400

Wani, S. H., Kumar, V., Shriram, V., and Sah, S. K. (2016). Phytohormones and their metabolic engineering for abiotic stress tolerance in crop plants. Crop J. 4 , 162-176. doi: 10.1016/j.cj.2016.01.010

Wu, H., Wu, X., Li, Z., Duan, L., and Zhang, M. (2012). Physiological evaluation of drought stress tolerance and recovery in cauliflower (Brassica oleracea L.) seedlings treated with methyl jasmonate and coronatine. J. Plant Growth Regul. 31, 113-123. doi: 10.1007/s00344-011-9224-x

Xiang, C., and Oliver, D. J. (1998). Glutathione metabolic genes coordinately respond to heavy metals and jasmonic acid in Arabidopsis. Plant Cell 1998, 1539-1550. doi: 10.1105/tpc.10.9.1539

Yan, Z., Chen, J., and Li, X. (2013). Methyl jasmonate as modulator of Cd toxicity in Capsicum frutescens var. fasciculatum seedlings. Ecotoxicol. Environ. Saf. 98, 203-209. doi: 10.1016/j.ecoenv.2013.08.019

Yan, Z., Zhang, W., Chen, J., and Li, X. (2015). Methyl jasmonate alleviates cadmium toxicity in Solanum nigrum by regulating metal uptake and antioxidative capacity. Biol. Plant 59, 373-381. doi: 10.1007/s10535-015-0491-4

Conflict of Interest Statement: The authors declare that the research was conducted in the absence of any commercial or financial relationships that could be construed as a potential conflict of interest.

Copyright (c) 2016 Per, Khan, Masood and Fatma. This is an open-access article distributed under the terms of the Creative Commons Attribution License (CC BY). The use, distribution or reproduction in other forums is permitted, provided the original author(s) or licensor are credited and that the original publication in this journal is cited, in accordance with accepted academic practice. No use, distribution or reproduction is permitted which does not comply with these terms. 